\title{
MALIGNANT HYPERTONIC HYPERPYREXIA SYNDROME
}

\author{
James A. Gibson, B.SC., M.D., C.M., ANd Douglas M. Gardiner, M.B., CH.B. ${ }^{\circ}$
}

SINCE 1966 approximately 20 case reports have appeared in medical literature which describe an abnormal reaction under anaesthesia characterized principally by muscle hypertonicity and hyperpyrexia. ${ }^{1-12}$ Usually these reactions have been associated with the use of succinylcholine. Two cases have occurred in our 250bed hospital within a nine-month period. They are presented here in an attempt to generate further interest in this most perplexing and lethal syndrome. Further research into this problem is urgently needed.

\section{CASE 1 (J.A.G.)}

Y.A.N., a 10-year-old (73 lb.) girl of French-Canadian descent was admitted January 22, 1968, for surgical revision of facial scars. Except for emergency treatment of her facial lacerations (under local anaesthetic) her surgical history was negative. She had no history of serious illness, cNs disease, myopathy, or blood dyscrasia. No member of her immediate family had ever been given succinylcholine.

One hour preoperatively morphine $5 \mathrm{mg}$ and hyoscine $0.4 \mathrm{mg}$ were administered. Anaesthesia was induced with sodium thiopentone $200 \mathrm{mg}$ followed by succinylcholine (Anectine) $40 \mathrm{mg}$ intravenously. Because of inadequate relaxation an additional $40 \mathrm{mg}$ of succinylcholine was injected. This did not produce a relaxed jaw. In retrospect the result of this medication was a state of increased jaw stiffness. With some difficulty a \#26 Collins tube was introduced and the patient was maintained on nitrous oxide, halothane, and oxygen. Ventilation was controlled for about ten minutes, at which time assistance was no longer required. No abnormality in pulmonary compliance was experienced.

As the surgeon excised a scar on the right cheek the blood was noted to be unusually dark. Immediate steps were taken to relieve this apparent cyanosis. The anaesthetic was changed to 1.5 per cent halothane in oxygen. Shortly thereafter the colour of the blood appeared to improve and surgery continued. For the next thirty minutes the patient's vital signs were static. The surgeon then made an incision in another operative site and once again the blood was noted to be dark. The administration of oxygen did not bring about an improvement, and the pulse, which had ranged between 120 and 140 beats per minute, was now no longer recordable. The drapes were thrown back in preparation for cardiac resuscitation and the existence of a profound state of generalized muscle spasm became evident.

External cardiac massage began without delay and resuscitative drugs were

-Department of Anaesthesia, St. Mary's Hospital, New Westminster, British Columbia. 
administered as needed. An ECG showed cardiac arrest in asystole. During the initial ten minutes of the cardiac arrest the asystole converted to a rather coarse fibrillation. At this point $10 \mathrm{cc}$ of calcium gluconate was injected into the heart and this was followed by external defibrillation. Immediately thereafter sinus rhythm was recorded. Unfortunately this was of short duration and soon reverted to ventricular fibrillation. External and internal defibrillation proved to be unsuccessful. The patient felt warm and the axillary temperature was found to be $104^{\circ} \mathrm{F}$.

The heart became totally unresponsive to all therapy and the pupils were dilated and fixed. Three hours after induction the patient was pronounced dead. The post-mortem findings were non-specific. Succinylcholine (Anectine) from the vial used in this case had been administered to a preceding patient without any adverse response.

Members of this family were notified that they might exhibit a lethal abnormal response to succinylcholine.

\section{CASE 2 (D.M.G.)}

S.L., an 80-pound seven-year-old white male had a history of chronic upper respiratory infections and was slated for $\mathbf{T} \& \mathrm{~A}$ and bilateral myringotomy. The patient's family are of English descent and are generally healthy. There are four brothers, one of whom had a herniotomy under ethyl chloride and ether anaesthesia and a myringotomy under nitrous oxide and Trilene. Succinylcholine was not used and no abnormal response was recorded. There is no known family history of abnormal response to anaesthesia.

The patient had been otherwise healthy. No abnormalities were noted at the preoperative examination, and the blood profile and urinalysis were both normal.

Premedication was with secobarbital gr $3 / 4$, meperidine $75 \mathrm{mg}$ and hyoscine $0.3 \mathrm{mg}$ at 6:30 AM. The child arrived in the operating room at 7:30 AM awake and calm. The temperature was $98.6^{\circ} \mathrm{F}$ and the pulse 100 beats per minute. Sleep was induced with thiopentone $100 \mathrm{mg}$ at $8: 35 \mathrm{AM}$. Immediately following this, succinylcholine (Anectine) $20 \mathrm{mg}$ was injected through the same needle. Solutions from both drug bottles had been used on previous patients with no untoward effect. Following the injection of succinylcholine no fasciculations were noted. The patient was ventilated with oxygen and chest compliance was unremarkable. On attempting to insert a laryngoscope the jaw was noted to be difficult to open. A further $40 \mathrm{mg}$ of succinylcholine was given with no relaxant effect. Intubation and insertion of a Boyle-Davis gag were completed with difficulty. Normal spontaneous breathing resumed after the usual period of apnoea. Maintenance of anaesthesia was with nitrous oxide and 50 per cent oxygen with halothane 1.5 per cent, the whole being delivered by an open circuit with a non-rebreathing valve. The adenoids were removed and then, towards the end of the first tonsillectomy at 8:50 AM, the respiratory pattern was noted to be changing, the breathing becoming more rapid and shallow. The halothane concentration was reduced and breathing was assisted. Adequate breathing resumed about five minutes later, 
and was deep but still quite rapid. Carpo-pedal spasm was noted at 9:07 AMI after the second tonsillectomy was started, and from then on oxygen only was given and respiration was controlled. At this time blood removed from the antecubital vein was very dark, although at the operative site it always appeared normal. The rectal temperature at 9:15 AM when the tonsillectomy had been completed was $103.4^{\circ} \mathrm{F}$ and despite sponging it was $105^{\circ} \mathrm{F}$ at $9: 25 \mathrm{AM}$, so cooling was begun on the table with icepacks, and preparations were made to transfer the patient to a scrub trough containing ice water. At this time calcium gluconate $0.5 \mathrm{gm}$ and $44.5 \mathrm{mEq}$ of sodium bicarbonate were given and both drugs repeated at frequent intervals. D-tubocurarine $45 \mathrm{mg}$ was given but with no obvious decrease of muscle spasm, which was now becoming extremely marked and generalized. Largactil $25 \mathrm{mg}$ was given prior to immersion in the trough at 9:50 AM when the temperature had reached $107.4^{\circ} \mathrm{F}$. A catheter specimen of urine was red. From this time the pupils were noted to be moderately dilated and unresponsive to light. A cardioscope connected at 10:00 AM showed a broadencd QRS and elevated T-wave and a few minutes later there was a brief period of ventricular tachycardia. Serum potassium at this time was $7.9 \mathrm{mEq}$, the other electrolytes and serum bicarbonate being normal. At 10:08 AM the temperature was $106.3^{\circ} \mathrm{F}$ and at 10:40 $\mathrm{AM}$ it was $94^{\circ} \mathrm{F}$; the systolic blood pressure at that time was $90 \mathrm{~mm} \mathrm{Hg}$. The patient was removed from the trough at 10:55 AM and at 11:05 AM the temperature was $82^{\circ} \mathrm{F}$, its lowest level. Peritoneal dialysis was established at 11:45 AM in an effort to lower the serum potassium level.

The patient's condition remained essentially unchanged. At 3:00 PM the serum potassium was $1.7 \mathrm{mEq}$, yet the cardioscope continued to show an elevated T-wave. The blood sugar was $330 \mathrm{mg}$ per cent. Toronto insulin was given to a total of 20 units. Potassium chloride was added to the intravenous infusion and at 4:00 PM the serum potassium had risen to $2.2 \mathrm{mEq}$, other electrolytes and bicarbonates being with normal limits. Serum calcium was reported normal in all specimens. At 7:00 PM the pulse rate began to rise to 120 beats per minute. Blood pressure was $80 / 40 \mathrm{~mm} \mathrm{Hg}$. The pupils were dilated and unreactive to light. At 9:00 PM the child's general condition appeared to improve and he opened his eyes on request. His temperature was then $96^{\circ} \mathrm{F}$ and his pulse was continuing to rise. At 11:45 PM the patient was responding by moving his limbs and his breathing needed only some assistance. However, he was becoming restless and objected to the endotracheal tube. The temperature was then $100^{\circ} \mathrm{F}$ and the pulse rate 150 beats per minute. At 1:00 AM bronchial secretions became a problem and a tracheostomy was done. The pulse was now 200 beats per minute and irregular. His pupils were dilated and fixed. The serum potassium was then $4.3 \mathrm{mEq} / \mathrm{L}$. By 1:45 AM his general condition had deteriorated and he developed ventricular fibrillation which reverted after DC electroshock. The temperature was beginning to rise again and at 2:30 AM had reached $103^{\circ} \mathrm{F}$. By 3:00 AM it was $105^{\circ} \mathrm{F}$. His general condition further deteriorated and he died at 6:00 AM.

Autopsy revealed pulmonary oedema of both lungs, congestion of the left lung and haemorrhage into the alveolar spaces and focal necrosis of individual heart muscle fibers. Intraocular potassium was $7 \mathrm{mEq} / \mathrm{L}$ and in the $\mathrm{csF}$ it was 39 $\mathrm{mEq} / \mathrm{L}$. 
The succinylchole (Anectine) used in this case was analysed by the Food and Drug Directorate, who found it to conform to the specifications for this product.

\section{Discussion}

A number of related syndromes ${ }^{15}$ have been reported recently in which hyperpyrexia and/or hypertonia are significant findings. In many instances succinylcholine seemed to be the triggering mechanism. Four diagnostic features common to our cases were: ( 1 ) hypertonia, including $(a)$ jaw stiffness and $(b)$ subsequent intensive generalized muscle spasm; (2) cyanosis, (3) hyperpyrexia, and (4) hyperkalaemia.

1. Hypertonia. The onset of masseteric spasm or hypertonicity in some other form appears to be immediate in most cases when succinylcholine is used but there are other cases where it has been noticed at a late stage of anaesthesia. There is a definite clinical difference between the intubation difficulty sometimes associated with anatomical abnormalities and that due to masseteric spasm. This is apparent in retrospect but it is easy to overlook at the time. Thus, prolonged muscle spasjn of the jaw, after succinylcholine has been given, is an important early warning sign. It is noteworthy that jaw stiffness occurred before halothane was used, and this has been the pattern in the majority of cases described. This would certainly suggest that halothane is not essential in the production of the initial jaw stiffness.

2. Cyanosis. In case 1 the apparent cyanosis did not totally resolve with high oxygen flows. The blood had an unusual dark hue. A retrospective reassessment led to a suspicion that the cyanosis was due not to excess reduced haemoglobin but to metmyoglobin in the plasma.

In case 2 the urine was red. It had a protein content of $225 \mathrm{mg}$. per cent and a microscopic of 1-3 RBC per high-powered field. What initially appeared to be a haemoglobinuria was probably, in fact, a myoglobinuria. This impression was substantiated by the fact that the haemoglobin did not fall as it would have done if the red colour of the urine had been due to a haemoglobinuria. Airaksinen and Tammisto ${ }^{13}$ reported that 30 per cent of normal patients exhibited a myoglobinuria when given serial doses of succinylcholine during a halothane anaesthetic. Spectrophotometric examination in their cases revealed the presence of metmyoglobin and oxymyoglobin in the urine. The cyanosis of metmyoglobin is not eliminated by oxygen and hence this may account for the refractory cyanosis of case 1 .

Smith ${ }^{14}$ reported a case of hyperpyrexia which he stated "proved to be due to myoglobinaemia." In two other cases ${ }^{5,6}$ haemoglobinuria was recorded. Since the initial urine tests would not have differentiated between haemoglobinuria and myoglobinuria, it is possible that a definitive diagnosis of myoglobinuria was missed. The results of these observations would suggest that an apparent cyanosis with accompanying myoglobinuria may be indicative of a malignant hypertonic cyanotic hyperpyrexic syndrome. 
3. Hyperpyrexia. Of all the causes of hyperpyrexia during anaesthesia this syndrome is distinctive because of the rapid, profound increase in temperature it produces. An increase of $1^{\circ} \mathrm{F}$ or more per fifteen minutes is not unusual. Because we do not routinely monitor body temperature during anaesthesia the initial phases of the hyperthermia may be missed. In case 1 the axillary temperature was recorded at $104^{\circ} \mathrm{F}$. In case 2 the temperature was $103^{\circ} \mathrm{F}$ forty-five minutes after induction, and it rose to $107^{\circ} \mathrm{F}$ per rectum in one hour and fifteen minutes. A progressive intense generalized spasm of muscles developed in both of our cases. It is probable that the massive muscle hypertonicity, by itself, was sufficient to produce a malignant hyperpyrexia.

4. Hyperkalaemia. Case 1 developed cardiac arrest in asystole. This was probably associated with a high serum potassium level. In case 2 the initial postreaction serum potassium level was $7.9 \mathrm{mEq} / \mathrm{L}$. This potentially lethal serum potassium level probably comes from damaged muscle cells.

It can be postulated that the hypertonic-hyperpyrexic syndrome is (1) a rare phenomenon in normal people or (2) a common response in people with myopathies (diagnosed or sub-clinical). In either case succinylcholine may trigger the adverse reaction. Patterson, ${ }^{1}$ Cody, ${ }^{10}$ and Thiel ${ }^{6}$ have recorded abnormal responses to succinylcholine in patients with myotonia congenita. It seems possible that patients with a myoglobinuric myopathy (McArdle's Disease) could react in an abnormal manner to succinylcholine. A familial pattern similar to myoglobinuric myopathy would seem to be borne out by Purkis et al., ${ }^{7}$ who recorded the malignant hyperthermic death of a 44-year-old female and her 14-year-old niece. We plan to evaluate the families of patients 1 and 2 to establish whether any of them have undiagnosed myoglobinuric myopathy.

Treatment is empirical and the results are not encouraging. The high mortality encountered is probably associated with the hyperpyrexia and hyperkalaemia. Cooling is an urgent necessity and should be vigorous from the outset. Rapid body cooling may be achieved by the use of (1) iced saline gastric lavage, (2) cold sterile solution put into the abdominal or thoracic cavity if they are open, or (3) subtotal immersion in ice water. The adverse cardiac effect of hyperkalaemia can be lessened by adequate dosage of calcium intravenously. Peritoneal dialysis would also seem to be an effective way of reducing serum potas-

sium. Following dialysis in case 2, serum potassium levels of 1.7, 2.2, and 3.3 $\mathrm{mEq} / \mathrm{L}$ were obtained; hence it is necessary to be aware of the possibility of iatrogenic hypokalaemia.

The administration of large doses of d-tubocurarine has been advocated as a means of reducing muscle spasm. In case $2,45 \mathrm{mg}$. of d-tubocurarine was given without any apparent beneficial effect.

\section{SUMMARY}

Two cases of a malignant hypertonic cyanotic hyperpyrexic syndrome which terminated in death are presented. Succinylcholine is suggested as the trigger mechanism in each case. Common diagnostic features were: (1) hypertonia, 
including $(a)$ jaw stiffness and $(b)$ subsequent intensive generalized muscle spasm; (2) cyanosis with an accompanying myoglobinuria; (3) malignant hyperpyrexia; and (4) hyperkalaemia. Abnormal jaw stiffness was evident following the use of succinylcholine. This appeared before the patient received halothane.

The results of treatment are discouraging. Cooling seems to be an urgent necessity and should be rigorous from the outset. Dangerous hyperkalaemia may be lessened by intravenous calcium gluconate and peritoneal dialysis. A possible association between myoglobinuric myopathy (McArdle's Disease) and this syndrome is suggested.

\section{RÉSUMÉ}

Nous présentons deux cas du syndrome d'hyperpyrexie avec cyanose et hypertonie, cas qui se sont terminés par la mort. Dans chaque cas, la succinylcholine semble être le facteur déclenchant du mécanisme. Les facteurs communs pour le diagnostic sont:

1. l'hypertonie (a) raideur du maxillaire et $(b)$ par la suite des spasmes musculaires intensifs généralisés;

2. une cyanose accompagnée de myoglobinurie;

3. une hyperpyrexie maligne;

4. une hyperkalihémie.

Après l'administration de la succinylcholine, nous avons noté une raideur du maxillaire et cela avant que le malade ne reçoive d'halothane.

Les résultats du traitement sont décourageants. Il semble de toute nécessité qu'il faille refroidir et, cela, dès le début et de façon vigoureuse. On peut diminuer l'hyperkalihémie dangereuse en administrant du gluconate de calcium par voie endoveineuse et faire une dialyse péritonéale. Ce syndrome nous fait penser à une certain association avec une myopathie (maladie de McArdle) à cause de la myoglobinurie.

\section{ACKNOWLEDGMENTS}

The authors wish to thank their medical colleagues who rendered assistance in the management of these cases. Provocative criticism by G. J. Fyffe, M.D., and G. W. Sleath, M.D., F.R.C.P.(C) has aided in the preparation of this report.

\section{REFERENCES}

1. Pattenson, I. S. Generalized Myotonia Following Suxamethonium: A Case Report. Brit. J. Anaesth. 34: 340 (1962).

2. Davies, L. E. \& Graves, H. B. Hyperpyrexia and Death Associated with General Anaesthesia. Canad. Anaesth. Soc. J. 13: 447 (1966).

3. Relton, J. E. S.; Creighton, R. E.; Johnston, A. E.; Pelton, D. A.; \& Conn, A. W. Hyperpyrexia in Association with General Anaesthesia in Children. Canad. Anaesth. Soc. J. 13: 419 (1966).

4. Thut, W. H. \& Davenpont, H. T. Hyperpyrexia Associated with Succinylcholineinduced Muscle Rigidity: A Case Report. Canad. Anaesth. Soc. J. 13: 425 (1966).

5. Cullen, W. G. Malignant Hyperpyrexia during General Anaesthesia: A Report of Two Cases. Canad. Anaesth. Soc. J. 13: 437 (1966).

6. Thiel, R. E. The Myotonic Response to Suxamethonium. Brit. J. Anaesth. 39: 815 (1967). 
7. Punxis, I. E.; Horreit, O.; Young, C. G.; Fleming, R. A. P.; \& Langlex, G. R. Hyperpyrexia during Anaesthesia in a Second Member of a Family with Associated Coagulation Defect Due to Increased Intravascular Coagulation. Canad. Anaesth. Soc. J. 14: 183 (1967).

8. Lavole, G. Hyperpyrexia during General Anaesthesia: A Case Report. Canad. Anaesth. Soc. J. 13: 444 (1966).

9. Relton, J. E. S.; Cheighton, R. E.; Conn, A. W.; \& Nabeta, S. Generalized Muscular Hypertonicity Associated with Ceneral Anaesthetic Management. Canad. Anaesth. Soc. J. 14: 22 (1967).

10. Cody, J. R. Muscle Rigidity Following Administration of Succinylcholine. Anesthesiology. 29: 159 (1968).

11. Jensen, K.; Bennike, H. K.; Hanel, H. K.; \& Olesen, H. Myoglobinuria Following Anaesthesia Including Suxamethonium. Brit. J. Anaesth. 40: 329 (1968).

12. Fosten, N. E. Personal communication: report of a death associated with hyperpyrexia and hypertonia (1968).

13. Airaksinen, M. M. \& Tammisto, T. Myoglobinuria after Intermittent Administration of Succinylcholine during Halothane Anaesthesia. Clin. Pharmacol. Therap. 7: 583 (1966)

14. Smit, R. M. Anaesthesia for Infants and Children. Third ed., Saint Louis: C. V. Mosby (1968).

15. Baitr, B. A. \& Kalow, W. Hyper-rigidity and Hyperthermia Associated with Anaesthesia. Ann. N.Y. Acad. Sc. 151: 947 (1968). 